\section{Physical and Chemical Characteristics of a Commercial Potting Substrate Amended with Vermicompost Produced from Two Different Manure Sources}

\author{
Gary R. Bachman ${ }^{1}$ and James D. Metzger ${ }^{2,3}$
}

ADDITIONAL INDEX WORDS. worm castings, compost consistency, uniformity

SUMMARY. Interest in using alternative materials for potting substrate is increasing in response to availability and rising costs of peat and other conventional materials. Vermicompost (VC) is one such material. It is important to understand physical and chemical changes in potting substrate when amended with VC produced from different waste sources, pig (PVC) and beef cattle (BVC) manure in this study. Distribution of particles greater than $2 \mathrm{~mm}$ decreased, particles 0.5 to $1 \mathrm{~mm}$ increased, and particles less than $0.5 \mathrm{~mm}$ remained unchanged as PVC and BVC amendment increased. Dry bulk density and water-holding capacity increased with increasing PVC and BVC amendment. Porosity and air volume were inversely related to VC amendment, decreasing with increasing VC amendment. Saturated substrate extract sampling revealed nitrate nitrogen, phosphorus, calcium, magnesium, zinc, copper, iron content as well as electrical conductivity increased with increasing PVC and BVC amendment.

$\mathrm{F}$ loriculture crops are mostly grown in lightweight potting substrates (Poole and Conover, 1979). These substrates are frequently composed of mixtures having sphagnum peatmoss combined with other materials such as vermiculite or perlite and formulated to achieve desirable physical and chemical properties. There are many different substrate formulations used for floriculture crops, and thus there is not a universal substrate formulation. Most research on potting substrate has focused on the manner in which different media compositions affect plant growth (Bunt, 1971; Fonteno, 1993).

Concerns of future availability, excessive environmental degradation, and higher prices have generated much interest in sphagnum peat alternatives (Barkham, 1993; Buckland, 1993; Robertson, 1993). Materials

This research was supported by funds from the Kiplinger Endowment for Floriculture. Salary and additional research support supported by State and Federal funds appropriated to the Ohio Agricultural Research and Development Center, The Ohio State University. Manuscript HCS 06-15.

This paper is based on a portion of the dissertation submitted by GRB in partial fulfillment of the requirements for the $\mathrm{PhD}$ degree in horticulture.

${ }^{1}$ Department of Agriculture, Illinois State University, Normal, IL 61790-5020

${ }^{2}$ Department of Horticulture and Crop Science, The Ohio State University, Columbus, OH 43210

${ }^{3}$ Corresponding author. E-mail: grbachm@ilstu.edu. being evaluated include seaweed and biosolid composts (Vendrame and Moore, 2005), composted urban plant waste (Benito et al., 2005), spent mushroom compost (Szmidt and Chong, 1995), and vermicompost (VC) (Atiyeh et al., 2000, 2001; Handreck, 1986).

Vermicomposts are produced using earthworms (Eisenia foetida) to break down and stabilize organic wastes. During feeding, earthworms fragment the waste, increase microbial activity, and result in a composting or humification effect on waste material. The VC is obtained as the organic waste passes through the earthworm gut and is oxidized by associated microorganisms. VC, as a result of their fine particle size and structure, are being used as organic fertilizers, soil amendments, and potting substrate components. The specific physical and chemical characteristics of $\mathrm{VC}$ are dependent on the material consumed by the earthworms; however, VC from similar origins have similar characteristics (Tomati et al., 1990). Besides serving as a source of organic matter, VC increase moistureholding capacity and provide nutrients (Atiyeh et al., 2001; Galli et al., 1990; Tomati et al., 1988).

Characterizations of changes in potting substrate properties that occur with the incorporation of $\mathrm{VC}$ are needed. This is especially true because $\mathrm{VC}$ can be produced from many different types of wastes. The objective of this research was to determine the differences in physical characteristics and available plant nutrient content of a commercial peat-based substrate amended with VC from two different agricultural sources and the potential suitability as a potting substrate.

\section{Materials and methods}

A commercial greenhouse substrate, Metro Mix 360 [MM360 (O.M. Scotts Co., Marysville, Ohio)] was amended with pig (PVC) or beef cattle (BVC) manure. MM360 is a potting substrate formulated from Canadian sphagnum peatmoss, horticultural-grade vermiculite, ground bark, processed bark ash, dolomitic lime, and a starter fertilizer charge. PVC consisted of separated pig solids processed by E. foetida in indoor flow through reactors and provided by Vermicycle Organics, Charlotte, N.C. BVC consisted of feedlot beef cattle manure, processed by E. foetida in upward migration bin reactors, and produced at Illinois State University, Normal. Processing manure wastes in these types of reactors typically takes $\approx 30$ to $60 \mathrm{~d}$.

PVC or BVC and MM360 were loaded into a rotary substrate mixer and blended for $3 \mathrm{~min}$ to ensure complete dispersal of the various components for each VC type and mix ratio: $0 \% \mathrm{VC}$ (control), $10 \% \mathrm{VC}$, $20 \% \mathrm{VC}, 40 \% \mathrm{VC}$, and $100 \% \mathrm{VC}$ by volume.

\begin{tabular}{llll}
\hline $\begin{array}{l}\text { Units } \\
\text { To convert U.S. to SI, } \\
\text { multiply by }\end{array}$ & U.S. unit & SI unit & $\begin{array}{l}\text { To convert SI to U.S., } \\
\text { multiply by }\end{array}$ \\
\hline 1 & $\%$ & $\mathrm{l} \mathrm{mL} / 100 \mathrm{~mL}$ & 1 \\
2.5400 & inch $(\mathrm{es})$ & $\mathrm{cm}$ & 0.3937 \\
25.4000 & inch $(\mathrm{es})$ & $\mathrm{mm}$ & 0.0394 \\
1 & $\mathrm{mmho} / \mathrm{cm}$ & $\mathrm{mS} \cdot \mathrm{cm}^{-1}$ & 1 \\
1.7300 & $\mathrm{oz} / \mathrm{inch}^{3}$ & $\mathrm{~g} \cdot \mathrm{cm}^{-3}$ & 0.5780 \\
1 & $\mathrm{ppm}$ & $\mathrm{mg} \cdot \mathrm{kg}^{-1}$ & 1 \\
$\left({ }^{\circ} \mathrm{F}-32\right) \div 1.8$ & ${ }^{\circ} \mathrm{F}$ & ${ }^{\circ} \mathrm{C}$ & $\left(1.8 \times{ }^{\circ} \mathrm{C}\right)+32$
\end{tabular}


Particle size distribution was obtained by screening three $100-\mathrm{g}$ air-dried samples of each VC type and ratio using U.S. standard sieves with screens having openings of 5,4 , $2,1,0.5$, and $0.25 \mathrm{~mm}$. The particle fractions retained on each sieve and the amount that passed through the smallest sieve and retained were weighed. The percentage of each sieve fraction was determined by dividing each retained particle fraction by the total weight of the substrate sample.

Physical property characteristics were determined using a modified procedure described by Gabriels et al. (1993) and included dry bulk density (DBD), porosity (POR), water-holding capacity (WHC), and air volume (AV). Samples from each of the VC types and mix ratios were thoroughly wetted in bulk batches. Substrate was placed into $10-\mathrm{cm}$ diameter round containers with a collar added to the top of the container. The containers were tapped three times on the countertop after each addition of substrate until filled. The collar was removed and excess substrate was sliced off carefully with a sharp knife so the level of the substrate was even with the top of the container. The container and wet substrate were weighed and the weight of the container subtracted. The substrate was placed into a forced-air drying oven and dried for $24 \mathrm{~h}$ at $80^{\circ} \mathrm{C}$ and weighed.

The baseline nutrient levels, substrate $\mathrm{pH}$, and electrical conductivity (EC) of the $0 \%, 10 \%, 20 \%, 40 \%$, and $100 \%$ amended substrates were determined for PVC and BVC through analysis performed at the Ohio State University Research and Extension Analytical Laboratory, Wooster (PVC) and A\&L Analytical Laboratories, Memphis, Tenn. (BVC). Five separate samples were collected within each substrate mix. Substrate sampling was performed using the saturated substrate extraction (SME) method for the macronutrients (Yeager et al., 1983). Substrate sampling for micronutrients also used the SME method with the exception that the water was substituted with a $0.005 \mathrm{M}$ diethylenetriamanepenta acetic acid solution (Berghage et al., 1987). The SME samples were analyzed using inductively coupled plasma analysis for phosphorus (P), potassium $(\mathrm{K})$, calcium $(\mathrm{Ca})$, magnesium $(\mathrm{Mg})$, manganese $(\mathrm{Mn})$, zinc $(\mathrm{Zn})$, copper $(\mathrm{Cu})$, and iron $(\mathrm{Fe})$, whereas nitrate nitrogen $\left(\mathrm{NO}_{3}-\mathrm{N}\right)$ was measured using an ion-specific electrode. Statistical analysis of all data was performed using analysis of variance and means were separated by Fisher's least significant difference.

\section{Results and discussion}

Particle size distribution. The effect of the addition of PVC and BVC to MM360 on particle size distribution is shown in Figures 1 A and $\mathrm{B}$, respectively. Because amendment of MM360 with either of the two VC produced nearly identical particle size distribution, the data are discussed in terms of the composite effects. The addition of VC to MM360 resulted in an increase in the percentage of particles less than $1 \mathrm{~mm}$ in diameter. There were 33\% more particles with diameters less than $1 \mathrm{~mm}$ in $20 \%$ VC compared with MM360. Particle sizes of 1.0 to 0.5 ,
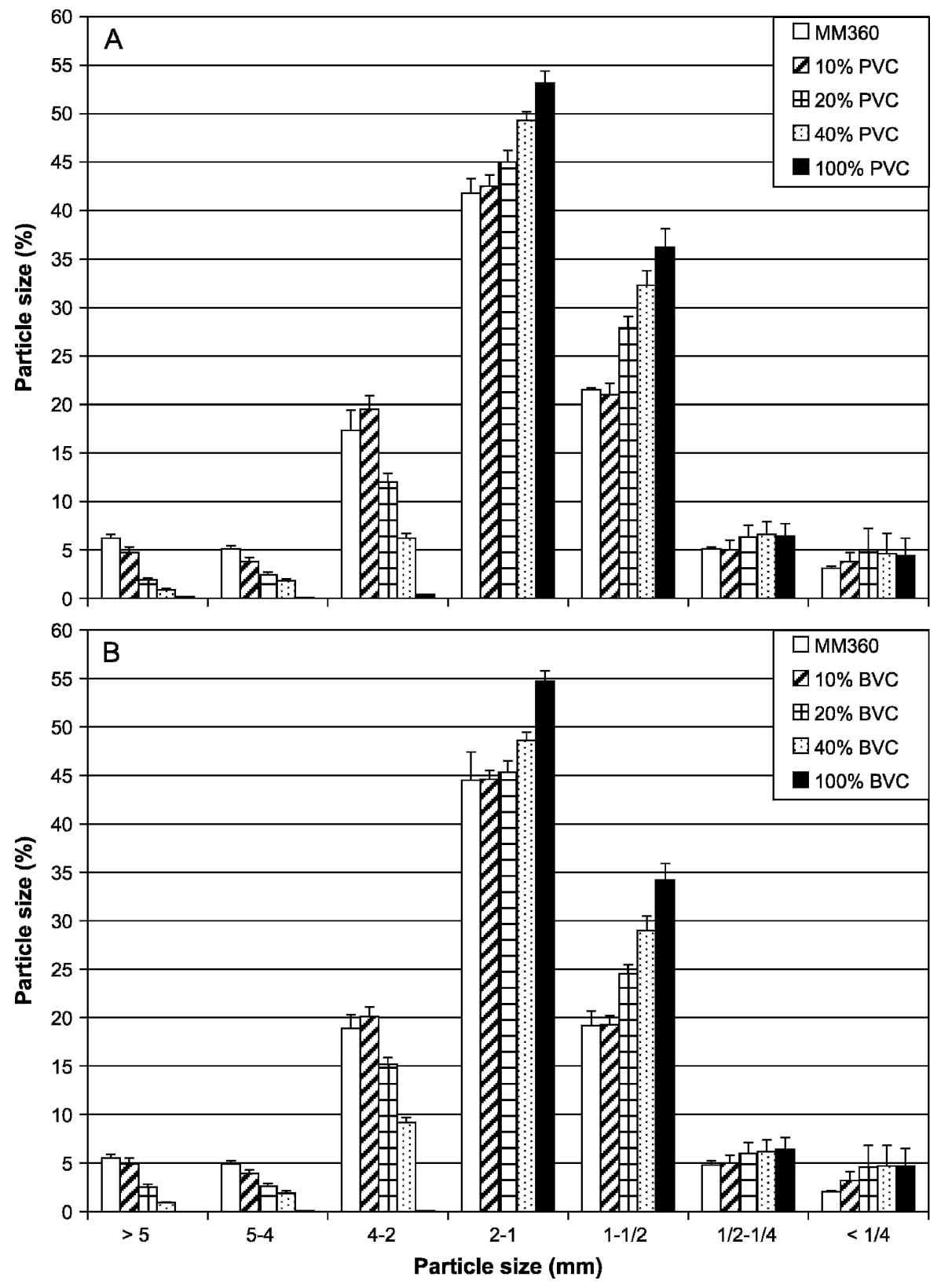

Fig. 1. Distribution of particle size ranges for a commercial potting substrate, Metro Mix 360 [MM360 (O.M. Scotts Co., Marysville, Ohio)], amended at five different levels by volume with vermicompost of (A) separated pig solids (PVC) or (B) feedlot beef cattle (BVC). Error bars represent $S E, \mathbf{n}=3$. 
0.5 to 0.25 , and less than $0.25 \mathrm{~mm}$ diameter increased $29 \%, 25 \%$, and $88 \%$ for $20 \% \mathrm{VC} ; 47 \%, 25 \%$, and $80 \%$ for $40 \% \mathrm{VC}$; and $65 \%, 27 \%$, and $69 \%$ for $100 \%$ VC compared with unamended (0\% VC) MM360 (Fig. 1). The proportion of particles with diameters greater than $1 \mathrm{~mm}$ decreased $15 \%$, $20 \%$, and $24 \%$ in $20 \% \mathrm{VC}$; and $40 \%$
VC, and 100\% VC, respectively. The greatest increases in particle size were those particles 1.0 to $0.5 \mathrm{~mm}$ in substrates with $\mathrm{VC}$ percentages above $20 \%$. The increases in 1.0 - to 0.5-mm particles corresponded with an inverse decrease in particle sizes $2 \mathrm{~mm}$ or greater. There was little difference between MM360 and 10\% VC in the proportion of particles with diameters between $0.25 \mathrm{~mm}$ and $2.0 \mathrm{~mm}$.

Physical PROperties. DBD and WHC increased as the proportion of VC was increased (Table 1). DBD increased $7 \%, 19 \%, 23 \%$, and $29 \%$ for $10 \% \mathrm{VC}, 20 \% \mathrm{VC}, 40 \% \mathrm{VC}$, and $100 \%$ $\mathrm{VC}$, respectively over unamended $0 \%$ $\mathrm{VC}$. Incorporation of $\mathrm{VC}$ increased

Table 1. Differences in physical properties of a commercial potting substrate, Metro Mix 360 [MM360 (O.M. Scotts Co., Marysville, Ohio)], amended at five different levels by volume with vermicompost (VC) of separated pig solids (PVC) or feedlot beef cattle (BVC).

\begin{tabular}{|c|c|c|c|c|}
\hline Substrate mix & $\begin{array}{l}\text { Bulk density } \\
\left(\mathrm{g} \cdot \mathrm{cm}^{-3}\right)^{\mathrm{z}}\end{array}$ & Porosity $(\mathrm{mL} / 100 \mathrm{~mL})^{\mathrm{y}}$ & $\begin{array}{c}\text { Water holding } \\
\text { capacity }(\mathrm{mL} / 100 \mathrm{~mL})^{\mathrm{x}}\end{array}$ & $\begin{array}{c}\text { Air volume } \\
(\mathrm{mL} / 100 \mathrm{~mL})^{x}\end{array}$ \\
\hline \multicolumn{5}{|c|}{ Separated pig solids vermicompost (PVC) } \\
\hline $10 \% \mathrm{PVC}$ & $0.13 \mathrm{c}$ & $92.63 \mathrm{~b}$ & $40.18 \mathrm{c}$ & $52.45 \mathrm{~b}$ \\
\hline $20 \%$ PVC & $0.15 \mathrm{~b}$ & $91.74 \mathrm{c}$ & $48.17 \mathrm{~b}$ & $43.57 \mathrm{c}$ \\
\hline $40 \%$ PVC & $0.16 \mathrm{ab}$ & $91.20 \mathrm{~cd}$ & $52.63 \mathrm{ab}$ & $40.63 \mathrm{c}$ \\
\hline \multicolumn{5}{|c|}{ Feedlot beef cattle vermicompost (BVC) } \\
\hline MM360 (control) & $0.12 \mathrm{c}$ & $91.23 \mathrm{a}$ & $35.68 \mathrm{e}$ & $55.55 \mathrm{a}$ \\
\hline $10 \% \mathrm{BVC}$ & $0.14 \mathrm{bc}$ & $87.75 \mathrm{~b}$ & $45.45 \mathrm{~d}$ & $42.30 \mathrm{~b}$ \\
\hline $20 \% \mathrm{BVC}$ & $0.16 \mathrm{~b}$ & $84.72 \mathrm{~b}$ & $52.02 \mathrm{c}$ & $32.70 \mathrm{c}$ \\
\hline $40 \% \mathrm{BVC}$ & $0.20 \mathrm{a}$ & $82.21 \mathrm{~b}$ & $55.87 \mathrm{~b}$ & $26.34 \mathrm{~d}$ \\
\hline $100 \% \mathrm{BVC}$ & $0.22 \mathrm{a}$ & $78.45 \mathrm{c}$ & $58.87 \mathrm{a}$ & $19.58 \mathrm{e}$ \\
\hline
\end{tabular}

${ }^{\mathrm{z}} 1 \mathrm{~g} \cdot \mathrm{cm}^{-3}=0.5780 \mathrm{oz} /$ inch $^{3}$

${ }^{y}$ Gravity equilibrated, drained wet substrate; $1 \mathrm{~mL} / 100 \mathrm{~mL}=1 \%$.

${ }^{x}$ Wet substrate.

${ }^{w}$ Mean separation among substrate mixes within each VC source.

${ }^{*},{ }^{\star *}$ Significant at $P \leq 0.05$ or 0.01 , respectively.

Table 2. Analysis of saturated substrate extract samples for a commercial potting substrate, Metro Mix 360 [MM360 (O.M. Scotts Co., Marysville, Ohio)], amended at five different levels by volume with vermicompost of separated pig solids or feedlot beef cattle.

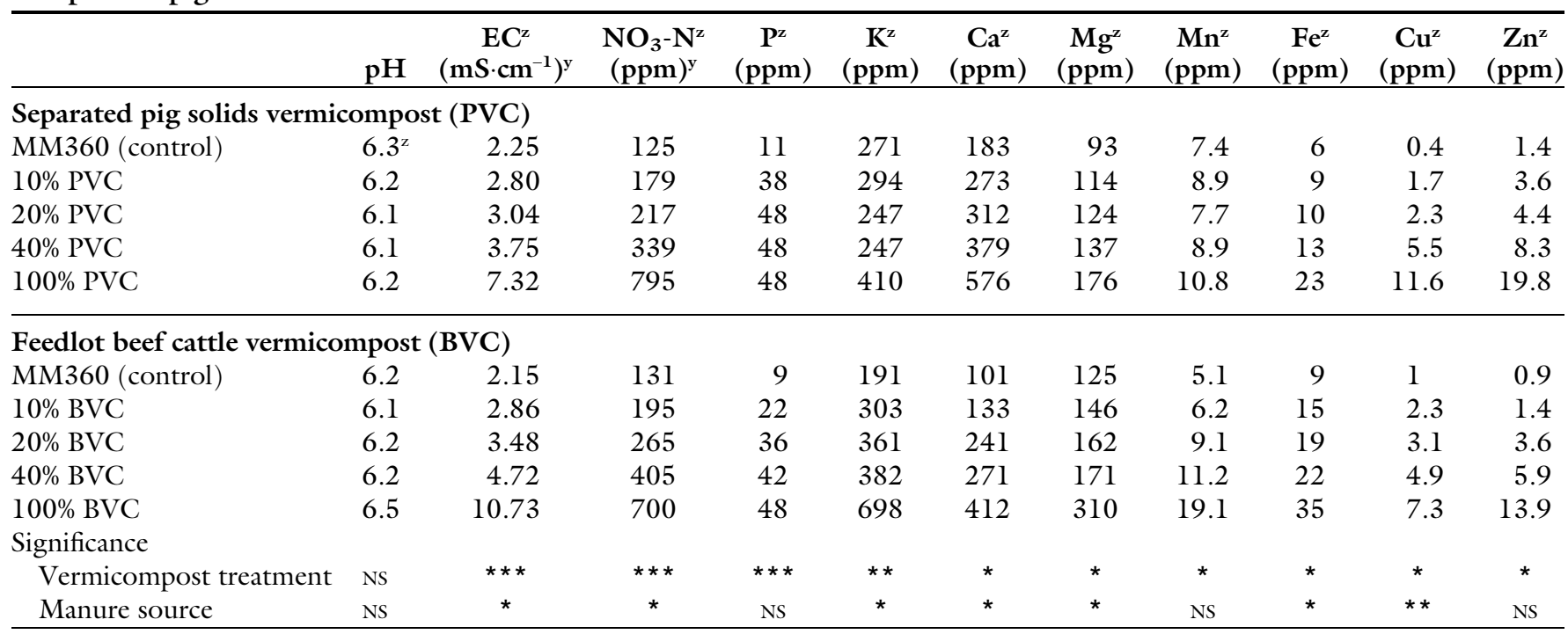

${ }^{\mathrm{z}} \mathrm{EC}=$ electrical conductivity $\mathrm{NO}_{3}-\mathrm{N}=$ nitrate nitrogen $\mathrm{P}=$ phosphorous $; \mathrm{K}=$ potassium $; \mathrm{Ca}=$ calcium; $\mathrm{Mg}=\mathrm{magnesium} ; \mathrm{Mn}=$ manganese $\mathrm{Fe}=$ iron; $\mathrm{Cu}=\mathrm{copper} ;$ $\mathrm{Zn}=$ zinc.

${ }^{\mathrm{y}} 1 \mathrm{mS} \cdot \mathrm{cm}^{-1}=1 \mathrm{mmho} / \mathrm{cm} ; \mathrm{l} \mathrm{ppm}=1 \mathrm{mg} \cdot \mathrm{kg}^{-1}$

Ns, $,,^{\star \star *},{ }^{* * *}$ Nonsignificant or significant at $P \leq 0.05,0.01$, or 0.001 , respectively. 
WHC $10 \%, 31 \%, 44 \%$, and $55 \%$ in $10 \% \mathrm{VC}, 20 \% \mathrm{VC}, 40 \% \mathrm{VC}$, and $100 \%$ $\mathrm{VC}$, respectively. Both AV and POR were inversely related to $\mathrm{DBD}$ and WHC (Table 1). As the percentage of $\mathrm{VC}$ incorporated increased, both AV and $\mathrm{P}$ decreased. The AV was lowered by $8 \%, 24 \%, 29 \%$, and $38 \%$ for $10 \%$ VC, $20 \% \mathrm{VC}$, and $40 \% \mathrm{VC}$, and $100 \%$ $\mathrm{VC}$, respectively. Amendment with $\mathrm{VC}$ resulted in lower substrate POR by $1 \%, 2 \%, 3 \%$, and $3 \%$ for $10 \% \mathrm{VC}$, $20 \% \mathrm{VC}$, and $40 \% \mathrm{VC}$, and $100 \% \mathrm{VC}$, respectively.

Nutrient content. Macronutrient content increased with increasing $\mathrm{VC}$ content regardless of VC type when compared with the unamended control substrate (Table 2). $\mathrm{NO}_{3}-\mathrm{N}$ increased by $43 \%, 73 \%$, and $270 \%$ (PVC) and 48\%, 202\%, and 309\% (BVC) in the $10 \%, 20 \%$, and $40 \%$ amended substrates compared with the control substrates, respectively. $\mathrm{P}$ was greater by $245 \%, 336 \%$, and $336 \%$ (PVC) and 144\%, 400\%, and $466 \%$ (BVC), whereas Ca increased $49 \%, 70 \%$, and $107 \%$ (PVC) and $37 \%$, $238 \%$, and $268 \%$ (BVC), respectively, in $10 \%, 20 \%$, and $40 \%$ amended substrate. $\mathrm{K}$ increased $8 \%$ in the $10 \%$ PVC and then decreased 9\% compared with the control substrate for $20 \%$ and $40 \%$ PVC. K increased 16\%, $29 \%$, and $37 \%$ compared the control substrate $10 \%, 20 \%$, and $40 \%$ BVCamended substrate, respectively.

The amendment of the control substrate with either PVC or BVC resulted in little change in substrate $\mathrm{pH}$ regardless of amendment volume (Table 2). EC conductivity increased with increasing amendment volumes of both PVC and BVC, 24\%, 35\%, and $67 \%$, and $53 \%, 61 \%$, and $219 \%$, respectively (Table 2 ). Substrate levels of $\mathrm{Mn}, \mathrm{Fe}, \mathrm{Cu}$, and $\mathrm{Zn}$ increased as both PVC and BVC amendment increased (Table 2).

Particle size distribution affects all physical properties within a potting container substrate (Spomer, 1975). In this study, there was an increase in the proportion of particles with diameters less than $2 \mathrm{~mm}$ in $20 \% \mathrm{VC}$ compared with unamended $0 \% \mathrm{VC}$ control, although there was little difference between $10 \% \mathrm{VC}$ to $0 \% \mathrm{VC}$. $\mathrm{DBD}$ and WHC increased in the $20 \%$ treatment as well as decreases in porosity and air volume. VC added at volumes above $20 \%$ resulted in substrate physical characteristics that may be optimal to produce quality floriculture crops. Gartner et al. (1974) reported that a favorable physical environment for plant growth resulted in a substrate having $20 \%$ to $40 \%$ particles less than $0.8 \mathrm{~mm}$ and $10 \%$ to $20 \%$ greater than $6.4 \mathrm{~mm}$. Tilt et al. (1987) reported that substrate particle size had significant effects on physical properties and plant growth of three species of woody ornamental plants. Substrate amended with peanut hulls increased particle size, porosity, and air space and decreased available water and bulk density (Bilderback et al., 1981). The increased particle size resulted in greater dry shoot weight, dry root weight, and percentage of growth. Substrate amended with peatmoss resulted in decreased particle size, porosity, and air space and led to reduced growth in azalea [Rhododendron sp. (Bilderback et al., 1981)].

Researchers have reported that the available $P$ in earthworm castings (VC) is usually greater than in surrounding soil (Lunt and Jacobson, 1944; Tiwari et al., 1989). The levels of $\mathrm{P}$ in $\mathrm{VC}$ are routinely five to 10 times greater than surface soils (Lee, 1985). Increased availability of $\mathrm{P}$ in VC compared with surrounding soil is proposed to be attributable to enhanced phosphatase activity in the VC (Satchell and Martin, 1984). This increased phosphatase activity is thought to be attributable to increased microbial activity. Evidence for this was reported by Sharpley and Syers (1976). Because P levels increased during the warmer seasons and decreased during winter, it was suggested that cool temperatures are responsible for reduced microbial activity.

The other macronutrients, particularly Ca, also increased with increased addition of VC (Tiwari et al., 1989). The chemistry of fecal material of earthworms is most likely responsible for the increased $\mathrm{Ca}$ found in VC. Earthworms have specialized glands that encapsulate the fecal material in calciferous deposits as it leaves the worms after passing through the worm gut (Piearce, 1972).

The micronutrient levels in the $100 \% \mathrm{VC}$ were great enough that in some species of bedding plants, there would be the threat of developing micronutrient toxicities. The concentrations that are considered optimal for potting substrate are 0.3 to $3.0 \mathrm{ppm} \mathrm{Fe}, 0.1$ to $3.0 \mathrm{ppm} \mathrm{Mn}$, 0.01 to $0.3 \mathrm{ppm} \mathrm{Cu}, 0.1$ to $0.3 \mathrm{ppm}$ $\mathrm{Zn}$, and 0.05 to $0.5 \mathrm{ppm} \mathrm{B}$ (Fafard Analytical Services, Anderson, S.C.). These levels decreased when less VC was added, although levels were still greater than what is considered optimal.

VC has the potential to be a beneficial amendment to potting media. Based on particle size analysis and physical properties, VC may be the most beneficial when used as an alternative supplemental component for peat or coir. Most potting substrates are composed of materials that contain a variety of particle sizes. This leads to changes in physical properties resulting from "nesting" of various particle sizes uniquely associated with soilless substrate components. The uniform particle size distribution of $\mathrm{VC}$ could provide predictable physical properties when blended with other substrate components. Changes in physical properties can result in growth enhancement or inhibition; therefore, additional studies must be conducted to determine optimal mix ratios with a variety of substrate components. Thus, the use of $\mathrm{VC}$ may reduce supplemental fertilizer applications or the need for the incorporation of nutrients ("starter charge") in media formulations. Incorporation of $\mathrm{VC}$ also increases WHC, which in turn could have a positive impact on water conservation and reduced water runoff.

\section{Literature cited}

Atiyeh, R.M., C.A. Edwards, S. Subler, and J.D. Metzger. 2001. Pig manure vermicompost as a component of a horticultural bedding plant medium: Effects on physiochemical properties and plant growth. Bioresour. Technol. 78:11-20.

Atiyeh, R.M., S. Subler, C.A. Edwards, G. Bachman, J.D. Metzger, and W. Shuster. 2000. Effects of vermicomposts and composts on plant growth in horticultural container substrate and soil. Pedobiologia (Jena) 44:579-590.

Barkham, J.P. 1993. For peat's sake: Conservation or exploitation? Biodivers. Conserv. 2:556-566.

Benito, M., A. Masaguer, R. Antonio, and A. Moliner. 2005. Use of pruning waste 
compost as a component in soilless growing substrate. Bioresour. Technol. 96: 597-603.

Berghage, R.D., D.M. Krauskpf, D.D. Warnke, and I. Widders. 1987. Micronutrient testing of plant growth substrate: Extractant identification and evaluation. Commun. Soil Sci. Plant Anal. 18:10891109.

Bilderback, T.E., W.C. Fonteno, and D.R. Johnson. 1981. Physical properties of substrate composed of peanut hull, pine bark, and peatmoss and their effects on azalea growth. J. Amer. Soc. Hort. Sci. 107:522-525.

Buckland, P. 1993. Peatland archeology: A conservation resource on the edge of extinction. Biodivers. Conserv. 2:513527.

Bunt, A.C. 1971. The use of peat-sand substrates for pot chrysanthemum culture. Acta Hort. 18:66-74.

Fonteno, W.C. 1993. Problems and considerations in determining physical properties of horticultural substrates. Acta Hort. 342:197-204.

Gabriels, R., W. Van Keirbuick, and H. Engels. 1993. A rapid method for determination of physical properties of growing substrate. Acta Hort. 342:243-247.

Galli, E., U. Tomati, A. Grappelli, and G. Di Lena. 1990. Effect of earthworm casts on protein synthesis in Agaricus-bisporus. Biol. Fertil. Soils 9:290-291.
Gartner, J.B., S.M. Still, and J.E. Klett. 1974. The use of bark waste as a substrate in horticulture. Acta Hort. 37:2003-2012.

Handreck, K.A. 1986. Vermicomposts as components of potting substrate. Biocycle 22:58-62.

Lee, K.E. 1985. Earthworms: Their ecology and relationships with soil and land use. Academic Press, Sydney.

Lunt, E.E. and G.M. Jacobson. 1944. The chemical composition of earthworm casts. Soil Sci. 58:367.

Piearce, T.G. 1972. The calcium relations of selected Lumbricidae. J. Anim. Ecol. 41:167-188.

Poole, R.T. and C.A. Conover. 1979. Light weight soilless mixes. Ornamentals South April:26-28.

Robertson, R.A. 1993. Peat, horticulture and environment. Biodivers. Conserv. 2:541-547.

Satchell, J.E. and K. Martin. 1984. Phosphatase activity in earthworm faeces. Soil Biol. Biochem. 16:191-194.

Sharpley, A.N. and J.K. Syers. 1976. Potential role of earthworm casts for the phosphorus enrichment of run-off waters. Soil Biol. Biochem. 8:341-346.

Spomer, A.L. 1975. Small soils containers as experimental tools: Soil water relations. Commun. Soil Sci. Plant Anal. 6:21-26.
Szmidt, R.A. and C. Chong. 1995. Uniformity of spent mushroom substrate (SMS) and factors in applying recommendations for use. Compost Sci. Util. 3:64-71.

Tilt, K.E., T.E. Bilderback, and W.C. Fonteno. 1987. Particle size and container size effects on growth of three ornamental species. J. Amer. Soc. Hort. Sci. 112:981-984.

Tiwari, S.C., B.K. Tiwari, and R.R. Mishra. 1989. Microbial populations, enzymes activities and nitrogen-phosphorus-potassium enrichment in earthworm casts and in surrounding soil of a pineapple plantation. Biol. Fertil. Soils 8:178-182.

Tomati, U., E. Galli, A. Grappelli, and G. Di Lena. 1990. Effect of earthworm casts on protein synthesis in radish (Raphanus sativum) and lettuce (Lactuca sativa) seedlings. Biol. Fertil. Soils 9:288-289.

Tomati, U., A. Grappelli, and E. Galli. 1988. The hormone-like effect of earthworm casts on plant growth. Biol. Fertil. Soils 5:288-294.

Vendrame, W. and K. Moore. 2005. Comparison of herbaceous perennial plant growth in seaweed compost and biosolids compost. Compost Sci. Util. 13:122-126.

Yeager, T.H., R.D. Wright, and S.J. Donohue. 1983. Comparison of pourthrough and saturated pine bark extract $\mathrm{N}, \mathrm{P}, \mathrm{K}$, and $\mathrm{pH}$ levels. J. Amer. Soc. Hort. Sci. 108:112-114. 